\title{
Pengaruh Suplementasi Vitamin A pada Pengobatan Pasien TB Paru terhadap Percepatan Konversi Dahak pada Fase Intensif Di Wilayah Kerja Puskesmas Kecamatan Medan Kota
}

\section{(Influence of Vitamin A Supplementation in Medication of Pulmonary TB Patients on Acceleration of Sputum Conversion in Intensive Phase in The Working Area of Medan Kota Sub District Puskesmas)}

\author{
ALEXANDER PARLINDUNGAN MARPAUNG ${ }^{1,2^{*}}$, PARLUHUTAN SIAGIAN ${ }^{3}$, DINA KEUMALA \\ $\mathrm{SARI}^{4}$
}

\author{
${ }^{1}$ Program Studi Magister Ilmu Kedokteran Tropis, Fakultas Kedokteran, Universitas Sumatera Utara \\ ${ }^{2}$ Departemen Mikrobiologi, Fakultas Kedokteran, Universitas Methodist Indonesia \\ ${ }^{3}$ Departemen Ilmu Penyakit Paru, Fakultas Kedokteran, Universitas Sumatera Utara \\ ${ }^{4}$ Departemen Ilmu Gizi, Fakultas Kedokteran, Universitas Sumatera Utara
}

Diterima 5 Juli 2018, Disetujui 29 Agustus 2018

\begin{abstract}
Abstrak: Indonesia merupakan negara dengan peringkat kedua untuk penderita kasus TB di dunia setelah India. Di Indonesia diperkirakan terdapat 1 juta kasus baru setiap tahun. Penelitian ini bertujuan untuk mengetahui pengaruh suplementasi vitamin A pada pengobatan pasien TB paru terhadap percepatan konversi dahak pada fase intensif di Wilayah Kerja Puskesmas Kecamatan Medan Kota. Desain studi uji klinis pendekatan studi eksperimental dengan metode Quasi Eksperimen. Sampel penelitian berjumlah 30 pasien, terdiri dari 15 orang kelompok perlakuan dan 15 orang kelompok kontrol. Sampel adalah penderita berusia $\geq 18$ tahun, mengkonsumsi OAT kategori I dengan teratur dan BMI $\geq 18,5$. Analisis statistik menggunakan uji Mann-Whitney pada taraf kepercayaan $95 \%(\mathrm{p}<0,05)$. Kelompok perlakuan, mayoritas berumur (18-27 tahun) 40,0\%, berjenis kelamin laki-laki 73,3\%, mayoritas mahasiswa 26,7\%, konversi BTA minggu ke-2 80,0\% dan rata-rata konversi sputum adalah 2,4 minggu. Kelompok kontrol mayoritas berumur 18-27 tahun 33,3\%, berjenis kelamin laki-laki 80,0\%, mayoritas mahasiswa dan wiraswasta masing-masing 20,0\%, konversi BTA minggu ke-4 $80,0 \%$ dan rata-rata konversi sputum adalah 4,1 minggu. Ada pengaruh suplementasi vitamin A pada pengobatan pasien TB paru terhadap percepatan konversi dahak pada fase intensif $(\mathrm{p}=<0,001)<($ alpha $=0,05)$. Ada pengaruh suplementasi vitamin A pada pengobatan pasien TB paru terhadap percepatan konversi dahak pada fase intensif di Wilayah Kerja Puskesmas Kecamatan Medan Kota.
\end{abstract}

Kata kunci: Vitamin A, konversi, fase fntensif, TB paru.

\begin{abstract}
Indonesia is the second rank for the most TB (Tuberculosis) cases in the world after India. It's estimated there are a million cases per year in Indonesia. The objective of the research was to find out the influence of Vitamin A supplementation in the medication of pulmonary TB on the acceleration of sputum conversion time at intensive phase in the Working Area of Puskesmas in Medan Kota Subdistrict. This research applied clinical testing design with experimental approach and Experimental Quasi method. The samples were 30 newly diagnosed pulmonary TB patients consisting of 15 patients in the treatment group and 15 patients in the control group. They were $\geq 18$ years old, regularly consumed category I OAT with BMI $\geq 18.5$. The statistical data were analyzed by Mann-Whitney statistical testing at reliability rate $95 \%(\mathrm{p}<0.05)$. The results of the research on the treatment group discovered that they were mostly $18-27$ years old $40.0 \%$, male $73.3 \%$, mostly university students $26.7 \%$, had BTA conversion in the second week $80.0 \%$; and the sputum conversion time was 2.4 weeks in average. The results of the research on the control group demonstrated that they were mostly $18-27$ years old $33.3 \%$, male $80.0 \%$, mostly university students and entrepreneurs $20.0 \%$, had BTA conversion in the second week $80 \%$; and the sputum conversion time was 4.1 weeks in average. Vitamin A supplementation in the medication of pulmonary TB patients had some influence on the acceleration of sputum conversion at intensive phase $(p=$ $<0.001)<($ alpha $=0.05)$. Vitamin A supplementation in the medication of pulmonary TB patients had some influence on the acceleration of sputum conversion at intensive phase in the Working Area of Puskesmas in Medan Kota Subdistrict. speed up wound healing on second degree burns. White egg gel had significantly difference compared to negative control of $\mathrm{NaCl} 0.9 \%$ and no significantly difference compared to Bioplacenton as positive control.
\end{abstract}

Keywords: White egg gel, burns, fibroblast, macrophage, colagen density, wound healing time.

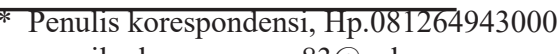

e-mail: alexmarpaung83@yahoo.com 


\section{PENDAHULUAN}

TUBERKULOSIS (TB) adalah suatu penyakit infeksi menular yang disebabkan oleh bakteri Mycobacterium tuberculosis, yang dapat menyerang berbagai organ terutama paru-paru. Penyakit ini bila tidak diobati atau pengobatannya tidak tuntas dapat menimbulkan komplikasi berbahaya hingga kematian. TB diperkirakan sudah ada di dunia sejak 5000 SM, namun kemajuan dalam penemuan dan pengendalian penyakit TB baru terjadi dalam dua abad terakhir ${ }^{(1)}$. Indonesia merupakan negara dengan peringkat kedua untuk penderita kasus TB di dunia setelah India. Di Indonesia diperkirakan terdapat 1 juta kasus baru pertahun, dua kali lipat dari perkiraan sebelumnya untuk kasus insiden jika dibandingkanpada tahun $2014^{(2)}$.

Pada tahun 2015 dilaporkan bahwa Sumatera Utara merupakan provinsi tertinggi keempat untuk kasus TB Baru setelah Jawa Barat, Jawa Timur dan Jawa Tengah. Jumlah kasus baru penderita TB paru (BTA) $(+)$ yang mendapat pengobatan di Sumatera Utara sebesar 16.946 orang, dengan keberhasilan pengobatan sebanyak 15.774 orang $(93,1 \%)^{(3)}$.

Berdasarkan data laporan tiga tahun terakhir untuk penyakit TB paru dari Dinas Kesehatan Kota Medan, dilaporkan pada tahun 2013 tercatat sebanyak 1586 kasus BTA (+). Dengan kasus terbesar ada di wilayah kerja puskesmas kecamatan Medan Kota yaitu sebanyak 200 penderita. Dan dilaporkan pada tahun 2014 tercatat sebanyak 1650 kasus BTA (+). Dengan kasus terbesar ada di wilayah kerja puskesmas kecamatan Medan Kota yaitu sebanyak 220 penderita. Selanjutnya dilaporkan pada tahun 2015 tercatat sebanyak 1576 kasus BTA (+). Dengan kasus terbesar ada di wilayah kerja puskesmas kecamatan Medan Kota sebesar 197 penderita $^{(4)}$.

Pada penelitian Sekarindah tahun 1992 diharapkan pemberian vitamin A sejumlah 2 x 200000IU pada penderita TB paru dengan OAT dapat meningkatkan imunitas seluler. Tujuan penelitian ini adalah menilai pengaruh pemberian vitamin A pada penderita tuberkulosis paru yang sedang mendapat OAT terhadap jumlah limfosit total, limfosit $\mathrm{T}$ total, sub populasi limfosit $\mathrm{T}$, kadar retinol plasma, dan keadaan klinik penderita. Kesimpulannya adalah pemberian vitamin A 2 × 200000 IU dalam 8 minggu mampu meningkatkan kadar vitamin $\mathrm{A}^{(5)}$.

Kekurangan vitamin A telah umum diamati pada pasien TB. Tingkat serum retinol yang rendah kembali ke normal setelah dilakukan pengobatan anti tuberkulosis. Kekurangan vitamin A diamati pada pasien TB mungkin telah berkontribusi untuk perkembangan penyakit tuberkulosis didalamnya atau kekurangan merupakan hasil dari hilangnya nafsu makan, kurangnya penyerapan usus, peningkatan kehilangan vitamin A dalam urin atau reaksi fase akut di $\mathrm{TB}^{(6)}$.

Hasil penelitian Pakkasi et al di Indonesia pada tahun 2010, salah satu hasil yang diperoleh menunjukkan bahwa kelompok pasien yang diberikan suplemen vitamin A mengalami percepatan konversi dahak rata-rata pada 2,1 minggu, dan untuk kelompok pasien yang diberikan plasebo mengalami percepatan konversi dahak rata-rata pada 2,5 $\operatorname{minggu}^{(7)}$.

Salah satu indikator yang digunakan dalam memantau pengobatan tuberkulosis paru adalah dengan conversion rate (angka konversi). Conversion Rate (angka konversi) adalah persentase pasien baru TB paru terkonfirmasi bakteriologis yang mengalami perubahan menjadi BTA (Bakteri Tahan Asam) negatif setelah menjalani masa pengobatan tahap awal ${ }^{(8)}$.

Berdasarkan uraian latar belakang di atas, maka peneliti berminat untuk meneliti pengaruh suplementasi vitamin A pada pengobatan pasien TB paru terhadap percepatan konversi dahak pada fase intensif di wilayah kerja Puskesmas Kecamatan Medan Kota.

\section{METODOLOGI PENELITIAN}

RANCANGAN PENELITIAN. Penelitian menggunakan jenis penelitian uji klinis dengan pendekatan studi eksperimental dengan metode Quasi Eksperimen. Penelitian dilaksanakan pada Bulan Mei 2017 sampai Oktober 2017 di Puskesmas Wilayah Kerja Kecamatan Medan Kota.

Populasi dan Sampel: Populasi pada penelitian adalah pasien TB Paru dengan BTA $(+)$ yang mengkonsumsi OAT Kategori 1 yang berusia diatas 18 tahun. Sampel dalam penelitian ini adalah pasien TB Paru dengan BTA $(+)$ yang memenuhi kriteria inklusi, dibagi menjadi dua kelompok, yaitu kelompok kontrol dan kelompok perlakuan. Sampel berjumlah 30 orang pasien yang terdiri dari 15 orang pasien kelompok kontrol dan 15 orang pasien kelompok perlakuan.

Kriteria Inklusi. Penderita usia $\geq 18$ tahun, lakilaki dan perempuan. Didiagnosis sebagai penderita TB paru dengan hasil pemeriksaan sputum BTA $(+)$ dengan pengobatan OAT kategori 1. Belum pernah mendapat pengobatan OAT sebelumnya. Bersedia ikut penelitian dan mengkonsumsi obat secara teratur selama penelitian ini. Penderita TB dengan IMT $\geq$ 18,5 .

Kriteria Eksklusi. Wanita hamil, penderita TB paru dengan DM, penderita yang mengalami efek samping berat dalam mengkonsumsi obat selama 
penelitian, penderita dengan penyakit gagal ginjal.

Variabel Penelitian. Terdiri dari Variabel dependen yaitu Konversi BTA, dan Variable independent yaitu OAT Kategori 1 dan OAT Kategori 1 ditambah Vitamin A.

Prosedur Kerja. Bahan pemeriksaan penelitian adalah dahak (sputum) dari sampel yang dicurigai menderita TB Paru kategori 1. Dahak ditampung di pot dahak dengan metode yang baik dan menggunakan teknik pengambilan dahak SPS (Sewaktu Pagi Sewaktu). Pemeriksaan dahak dilakukan di laboratorium menggunakan metode pewarnaan Ziehl Neelsen. Hasil pewarnaan Ziehl Neelsen diperiksa secara mikroskopis untuk mendeteksi bakteri Mycobacterium tuberculosis. Hasil pengamatan mikroskopis dihitung menggunakan Skala IUATLD (International Union Against Tuberculosis and Lung Disease).

Pasien yang menderita TB Paru kategori 1 yang memenuhi kriteria inklusi, di awal penelitian diberikan penjelasan tentang tujuan penelitian, prosedur penelitian dan manfaat penelitian. Pasien yang bersedia untuk ikut dalam penelitian diminta mengisi dan menandatangani lembar inform consent, lembar persetujuan meminum obat secara teratur, dan bersedia mengisi chek list meminum obat secara teratur.

Pasien yang memenuhi kriteria inklusi dan bersedia ikut dalam penelitian dibagi dalam dua kelompok. Kelompok pertama adalah kelompok kontrol yang diberikan pengobatan OAT kategori 1. Kelompok kedua adalah kelopok perlakuan yang diberikan OAT kategori 1 ditambah vitamin A 6000 IU. Kedua kelompok diamati selama dua bulan pertama pengobatan TB paru kategori 1 (fase intensif). Pengobatan OAT kategori 1 kepada kedua kelompok disesuaikan dengan ketetapan dosis fase intensif Depkes RI, dan pemberian vitamin A 6000 IU dengan dosis satu tablet perhari pada kelompok perlakuan dilakukan selama fase intensif atau sampai batas pemeriksaan sputum telah mengalami konversi (negatif).

Pengamatan dilakukan dengan pemeriksaan dahak secara berkala, pemeriksaan berkala dilakukan satu kali per-dua minggu selama fase intensif (minggu 2, minggu 4, minggu 6 dan minggu 8). Bila hasil pemeriksaan dahak secara berkala pada setiap penderita masing-masing kelompok telah mengalami konversi, maka pengobatan OAT tetap dilanjutkan sesuai dengan ketetapan Depkes RI, tetapi pemberian Vitamin A 6000IU dihentikan. Pada saat dahak sudah mengalami konversi, maka kembali dilakukan pemeriksaan Indeks Massa Tubuh (IMT) penderita Analisis data secara komputerisasi dengan bantuan aplikasi SPSS 21 menggunakan uji Mann Whitney pada tingkat kepercayaan $95 \%$ dan dianggap bermakna bila $\mathrm{p}<0,05^{(9)}$.

\section{HASIL DAN PEMBAHASAN}

Umur. Hasil penelitian didapat umur terbanyak 18-27 pada kelompok perlakuan sebanyak 6 orang (40,0\%) dan pada kelompok kontrol sebanyak 5 orang (33,3\%). Menurut laporan Kemenkes RI (2012) sekitar $75 \%$ pasien TB adalah kelompok usia yang paling produktif secara ekonomis (15-50 tahun). Hal ini diketahui bahwa kelompok umur produktif sangat rentan terkena penularan penyakit TB Paru, dimana pada usia produktif ini tingkat mobilitas sangat tinggi dan sering berinteraksi dengan orang lain di sekitarnya $^{(10)}$. WHO (2013) menyatakan bahwa 75\% dari semua kasus TB adalah di antara orang-orang yang berusia 15-54 tahun ${ }^{(11)}$.

Jenis Kelamin. Hasil penelitian kelompok perlakuan mayoritas laki-laki 11 orang $(73,3 \%)$ dan perempuan sebanyak 4 orang $(26,7 \%)$, sedangkan untuk kelompok kontrol laki-laki sebanyak 12 orang $(80,0 \%)$ dan perempuan sebanyak 3 orang $(20,0 \%)$. Hal ini sesuai dengan laporan WHO (2015) diperkirakan ada 9,6 juta kasus baru TB paru yang terdiri dari proporsi laki-laki $(56,2 \%)$ lebih banyak dari perempuan yaitu (33,3\%) dengan 3,2 juta kasus diantaranya adalah perempuan. Terdapat 1,5 juta kematian karena TB dimana 480.000 kasus adalah perempuan $^{(2)}$.

Hasil penelitian ini sama dengan laporan Kemenkes RI (2013) bahwa prevalensi TB paru pada laki-laki lebih besar jika dibandingkan dengan perempuan $(0,4: 0,3)^{(12)}$. Hal ini diketahui bahwa laki-laki sebagai kepala keluarga dan pencari nafkah yang lebih sering beraktifitas diluar rumah lebih rentan terhadap penularan penyakit TB Paru. Menurut jenis kelamin, jumlah perlakuan pada laki-laki lebih tinggi dari pada perempuan yaitu 1,5 kali dibandingkan pada perempuan $^{(3)}$.

Pekerjaan. Berdasarkan pekerjaan, subjek penelitian secara keseluruhan pasien, mayoritas adalah mahasiswa sebanyak 7 orang $(23,3 \%)$. Untuk kelompok perlakuan sebanyak 4 orang $(26,7 \%)$ dan untuk kelompok kontrol sebanyak 3 orang $(20,0 \%)$. Hasil penelitian ini sesuai dengan yang dikemukakan oleh Kemenkes RI (2013) bahwa prevalensi TB paru paling besar pada pasien yang tidak bekerja $(11,7)^{(12)}$. Seorang pasien TB dewasa akan kehilangan ratarata waktu kerjanya 3 sampai 4 bulan. Hal tersebut berakibat kehilangan pendapatan tahunan rumah tangganya sekitar $20-30 \%{ }^{(10)}$. 
Tabel 1. Distribusi umur, jenis kelamin dan pekerjaan pasien TB paru pada kelompok perlakuan dan kelompok kontrol di wilayah kerja Puskesmas kecamatan Medan Kota.

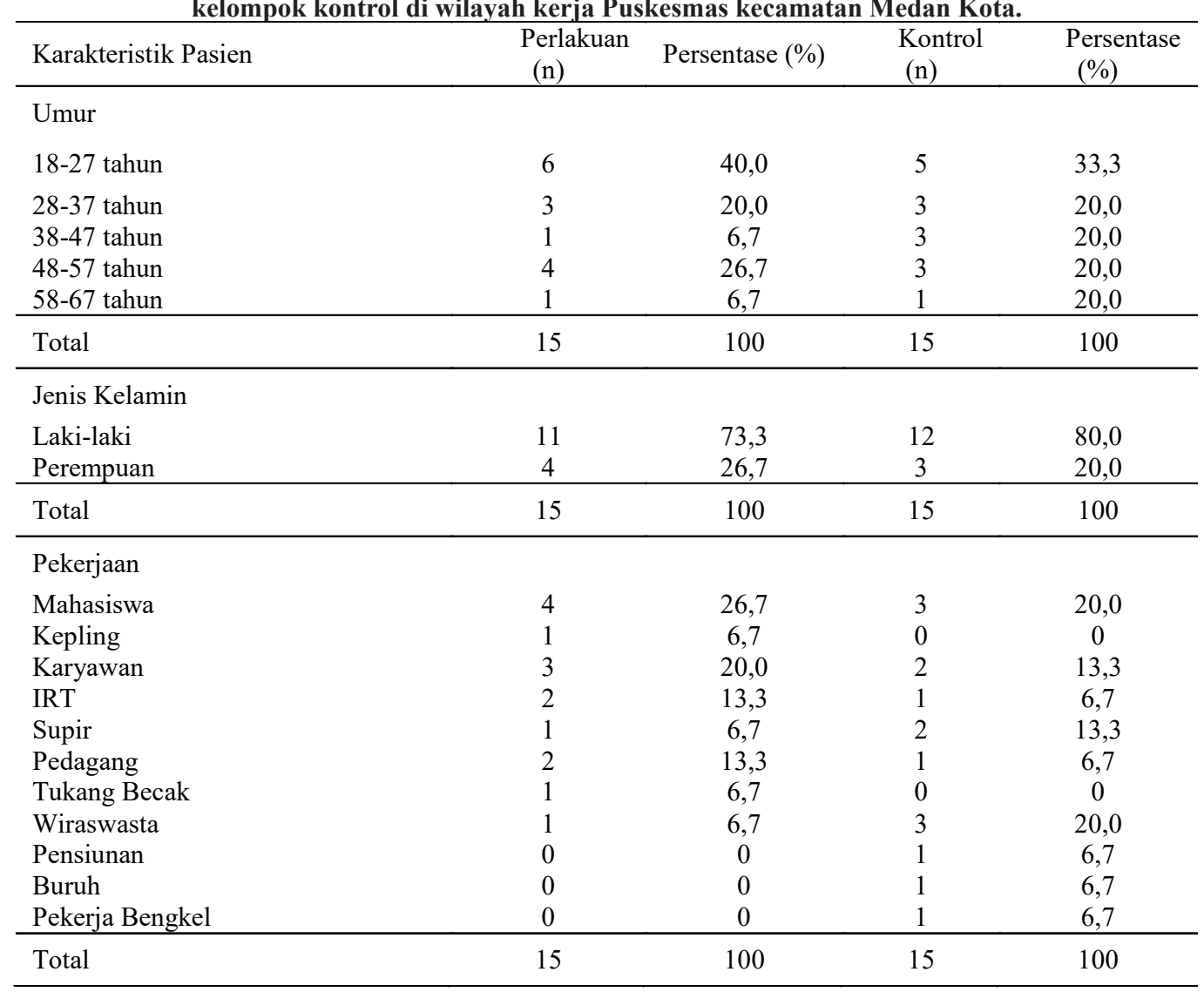

Pemeriksaan BTA dan Rata-rata Konversi. Berdasarkan pemeriksaan BTA dikelompokkan menjadi, 1+, 2+, 3+. Hasil pemeriksaan BTA pasien kelompok perlakuan mayoritas $3+$ sebanyak 9 orang (60,0\%) dengan rata-rata konversi 2,7 minggu. Kelompok kontrol mayoritas hasil pemeriksaan BTA pasien adalah $3+$ sebanyak 9 orang $(60,0 \%)$ dengan rata-rata konversi 4,4 minggu. Pada penelitian ini didapati baik kelompok perlakuan maupun kontrol, sampel terbanyak adalah TB paru dengan pemeriksaan BTA 3+. Hasil penelitian ini sejalan dengan penelitian
Tsani (2011) yang mendapatkan hasil dari 140 penderita TB paru, mayoritas hasil pemeriksaan BTA adalah $3+$ sebanyak 95 penderita $^{(13)}$.

Konversi BTA dan Rata-rata Waktu Konversi. Hasil penelitian pada kelompok perlakuan (pemberian suplemen vitamin A) hasil konversi BTA mayoritas pada minggu ke-2 sebanyak 12 orang $(80,0 \%)$, pada kelompok kontrol (tanpa pemberian suplemen vitamin A) mayoritas hasil konversi BTA pada minggu ke-4 sebanyak 12 orang $(80,0 \%)$. Pada kelompok perlakuan diperoleh rata-rata konversi

Tabel 2. Hasil pemeriksaan BTA pasien TB paru dan rata-rata konversi pada kelompok perlakuan dan kontrol di wilayah kerja Puskesmas kecamatan Medan Kota.

\begin{tabular}{|c|c|c|c|c|c|c|c|c|c|c|}
\hline \multirow{3}{*}{ BTA } & \multicolumn{2}{|c|}{ Perlakuan } & \multirow{2}{*}{\multicolumn{3}{|c|}{$\begin{array}{l}\text { Konversi BTA } \\
\text { (Minggu ke) }\end{array}$}} & Kontrol & \multirow{2}{*}{\multicolumn{4}{|c|}{$\begin{array}{c}\text { Konversi BTA } \\
\text { (Minggu ke) }\end{array}$}} \\
\hline & $\mathrm{n}$ & $\%$ & & & & & & & & \\
\hline & & & & 4 & 6 Rata-rata & & & 4 & 6 & Rata-rata \\
\hline $1+$ & 4 & 26,7 & 4 & 0 & 2,0 & 320,0 & 1 & 2 & 0 & 3,3 \\
\hline $2+$ & 2 & 13,3 & 2 & 0 & 2,0 & 320,0 & 0 & 3 & 0 & 4,0 \\
\hline $3+$ & 9 & 60,0 & 6 & 3 & 2,7 & 960,0 & 0 & 7 & 2 & 4,4 \\
\hline Total & 15 & 100 & & & & $15 \quad 100$ & & & & \\
\hline
\end{tabular}


2,4 minggu dan pada kelompok kontrol rata-rata 4,1 minggu. Hasil penelitian ini sejalan dengan penelitian Pakkasi et al di Indonesia pada tahun 2010 bahwa kelompok pasien yang diberikan suplemen vitamin A mengalami percepatan konversi dahak rata-rata pada 2,1 minggu $^{(7)}$. Hasil penelitian ini juga sejalan dengan penelitian Ahmad et al di India pada tahun 2012 bahwa suplemen vitamin A mengalami percepatan terbaik konversi dahak rata-rata pada 4,3 minggu. Hasil penelitian membuktikan bahwa pasien TB paru yang mendapat pengobatan OAT kategori I dan diberi suplemen vitamin A lebih cepat mengalami konversi BTA jika dibandingkan dengan pasien tanpa pemberian suplemen vitamin A yang hanya mendapat pengobatan OAT kategori $\mathrm{I}^{(14)}$.

IMT Pasien. Kelompok perlakuan mayoritas hasil perbandingan IMT sebelum dan setelah konversi menunjukkan kenaikan dengan rata-rata IMT sebelum pengobatan adalah 21,39, rata-rata IMT setelah konversi 21,62 dan rata-rata kenaikan IMT adalah 0,23. Kenaikan IMT yang paling besar ada pada pasien dengan nomor responden 13 yaitu

Tabel 3. Konversi BTA dan rata-rata waktu konversi pada pasien TB paru kelompok perlakuan dan kontrol di wilayah kerja Puskesmas Kecamatan Medan Kota.

\begin{tabular}{cccccc}
\hline $\begin{array}{c}\text { Konversi BTA } \\
\text { Perlakuan }\end{array}$ & $(\mathrm{n})$ & $\begin{array}{c}\text { Persentase } \\
(\%)\end{array}$ & $\begin{array}{c}\text { Konversi BTA } \\
\text { Kontrol }\end{array}$ & $(\mathrm{n})$ & $\begin{array}{c}\text { Persentase } \\
(\%)\end{array}$ \\
\hline Minggu ke-2 & 12 & 80,0 & Minggu ke-2 & 1 & 6,7 \\
Minggu ke-4 & 3 & 20,0 & Minggu ke-4 & 12 & 80,0 \\
Minggu ke-6 & 0 & 0 & Minggu ke-6 & 2 & 13,3 \\
Minggu ke-8 & 0 & 0 & Minggu ke- & 0 & 0 \\
\hline Total & 15 & 100 & Total & 15 & 100 \\
\hline Jumlah nilai & 36 & & Jumlah nilai & \\
konversi & & konversi Kontrol & 62 & \\
Perlakuan & & Rata-rata Konversi & $62 / 15=4,1$ \\
minggu & \\
Rata-rata & $36 / 15=2,4$ & & & \\
Konversi & minggu & & &
\end{tabular}

Tabel 4 IMT Pasien TB Paru sebelum Pengobatan dan setelah Konversi pada Kelompok Perlakuan dan Kontrol di Wilayah Kerja Puskesmas Kecamatan Medan Kota

\begin{tabular}{|c|c|c|c|c|c|c|c|c|}
\hline \multirow[b]{2}{*}{ No } & \multicolumn{4}{|c|}{ Perlakuan } & \multicolumn{4}{|c|}{ Kontrol } \\
\hline & $\begin{array}{c}\text { IMT } \\
\text { sebelum } \\
\text { Pengobatan }\end{array}$ & $\begin{array}{l}\text { IMT setelah } \\
\text { Konversi }\end{array}$ & Hasil & Ket & $\begin{array}{l}\text { IMT sebelum } \\
\text { Pengobatan }\end{array}$ & $\begin{array}{l}\text { IMT setelah } \\
\text { Konversi }\end{array}$ & Hasil & Ket \\
\hline 1 & 21,64 & 21,95 & 0,31 & Naik & 20,03 & 20,54 & 0,51 & Naik \\
\hline 2 & 19,87 & 20,16 & 0,29 & Naik & 24,03 & 24,64 & 0,61 & Naik \\
\hline 3 & 23,57 & 23,82 & 0,25 & Naik & 21,07 & 21,33 & 0,26 & Naik \\
\hline 4 & 23,91 & 24,11 & 0,20 & Naik & 20,33 & 21,20 & 0,87 & Naik \\
\hline 5 & 20,77 & 20,98 & 0,21 & Naik & 24,21 & 24,49 & 0,28 & Naik \\
\hline 6 & 20,00 & 19,91 & $-0,09$ & Turun & 19,83 & 20,60 & 0,77 & Naik \\
\hline 7 & 26,26 & 26,52 & 0,26 & Naik & 21,02 & 21,47 & 0,45 & Naik \\
\hline 8 & 18,93 & 19,15 & 0,22 & Naik & 18,78 & 19,33 & 0,55 & Naik \\
\hline 9 & 23,12 & 23,36 & 0,24 & Naik & 19,05 & 19,79 & 0,74 & Naik \\
\hline 10 & 18,78 & 18,99 & 0,21 & Naik & 25,81 & 26,21 & 0,40 & Naik \\
\hline 11 & 19,59 & 19,75 & 0,16 & Naik & 22,70 & 23,42 & 0,72 & Naik \\
\hline 12 & 21,52 & 21,60 & 0,08 & Naik & 22,27 & 22,35 & 0,08 & Naik \\
\hline 13 & 22,70 & 23,37 & 0,67 & Naik & 24,14 & 24,69 & 0,55 & Naik \\
\hline 14 & 21,29 & 21,51 & 0,22 & Naik & 20,36 & 20,80 & 0,44 & Naik \\
\hline 15 & 18,97 & 19,15 & 0,18 & Naik & 22,69 & 23,07 & 0,38 & Naik \\
\hline Jumlah & 320,92 & 324,33 & 3,41 & & 326,32 & 333,93 & 7,61 & \\
\hline Total sampel & 15 & 15 & 15 & & 15 & 15 & 15 & \\
\hline $\begin{array}{l}\text { Rata-rata } \\
\text { IMT }\end{array}$ & $\begin{array}{c}320,92 / 15 \\
=21,39\end{array}$ & $\begin{array}{c}324,33 / 15= \\
21,62\end{array}$ & & & $\begin{array}{c}326,32 / 15 \\
=21,75\end{array}$ & $\begin{array}{c}333,93 / 15= \\
22,26\end{array}$ & & \\
\hline $\begin{array}{c}\text { Rata-rata } \\
\text { selisih IMT }\end{array}$ & & & $\begin{array}{c}3,41 / 15= \\
0,23\end{array}$ & & & & $\begin{array}{l}, 61 / 15= \\
0,51\end{array}$ & \\
\hline
\end{tabular}


sebesar 0,67. Pada kelompok kontrol mayoritas hasil perbandingan IMT sebelum pengobatan dan setelah konversi menunjukkan kenaikan dengan rata-rata IMT sebelum pengobatan 21,75, rata-rata IMT setelah konversi 22,26 dan rata-rata kenaikan IMT 0,51 . Kenaikan IMT paling besar pada pasien nomor responden 4 sebesar 0,87 .

Adanya hubungan kausal dua arah yang jelas antara kekurangan gizi dan TB aktif, penilaian dan pengelolaan nutrisi merupakan hal yang integral dari komponen pengobatan dan perawatan TB. TB membuat kurang gizi dan kekurangan gizi memperlemah kekebalan tubuh, sehingga meningkatkan kemungkinan TB laten akan berkembang menjadi penyakit aktif. Kebanyakan individu dengan TB aktif berada dalam keadaan katabolik dan mengalami penurunan berat badan dan beberapa tanda menunjukkan kekurangan vitamin dan mineral saat diagnosis. Penurunan berat badan diantara mereka yang menderita TB bisa disebabkan oleh beberapa faktor, diantaranya mengurangi asupan makanan akibat kehilangan nafsu makan mual dan sakit perut, kehilangan gizi akibat muntah dan diare. Indeks massa tubuh rendah (BMI) (lebih rendah dari $18,5 \mathrm{~kg} / \mathrm{m}^{2}$ ) dikaitkan dengan peningkatan risiko kematian, kambuh kembali dan dapat menjadi indikasi keparahan TB. Terapi TB yang efektif akan memperbaiki status gizi dengan meningkatkan nafsu makan dan asupan makanan dan meningkatkan efisiensi metabolisme ${ }^{(11)}$.

Indeks massa tubuh (BMI) di bawah 18,5 meningkatkan risiko TB sebanyak 2-3 kali. Sebaliknya, kenaikan berat badan akan menurunkan risikonya. Rata-rata IMT meningkat pada pasien yang sembuh pada akhir pengobatan jika dibandingkan dengan
Puskesmas Kecamatan Medan Kota. Dengan semakin cepatnya terjadi konversi BTA dari pasien maka akan diikuti dengan angka kesembuhan yang tinggi pula dan tingkat penularan yang semakin berkurang. Penelitian ini sejalan dengan penelitian Pakkasi tahun 2009 bahwa ada korelasi rendahnya vitamin A terhadap keparahan TB dengan nilai $\mathrm{P}=0,000^{(16)}$.

Penelitian Karyadi dkk (2002) bahwa suplemen vitamin A dan zink memperbaiki efek terapi TB setelah 2 bulan $^{(17)}$.

Telah banyak diketahui, status nutrisi yang rendah ditemukan lebih sering terjadi pada penderita tuberkulosis aktif dibandingkan orang sehat. Tuberkulosis dapat menyebabkan berat badan dibawah normal dan defisiensi mikronutrien (multivitamin dan mineral) karena terjadinya malabsorpsi, meningkatnya kebutuhan energi, terganggunya proses metabolik dan berkurangnya asupan makanan karena penurunan nafsu makan dan dapat mengarah terjadinya kondisi wasting. Defisiensi mikronutrien telah dilaporkan pada penderita tuberkulosis, termasuk juga mereka yang dengan koinfeksi HIV. Penelitian-penelitian secara cross sectional mengindikasikan defisiensi vitamin A, tiamin, vitamin B6, folat dan vitamin E sering terjadi pada penderita TB aktif. Defisiensi vitamin A, vitamin E, tiamin, riboflavin, vitamin B6 dan vitamin $\mathrm{C}$ lebih umum terjadi penderita TB dengan HIV. Defisiensi mikronutrien dan status gizi umum yang jelek pada penderita TB aktif dapat menekan sistem imun cellmediated yang merupakan pertahanan utama host untuk melawan bakteri Mycobacterium ${ }^{(18)}$.

Defisiensi vitamin A menyebabkan berkurangnya nafsu makan. Hal ini karena perubahan pada jonjot rasa pada lidah. Vitamin A juga berpengaruh

Tabel 5. Analisis pengaruh suplementasi vitamin A terhadap konversi BTA pada pasien TB Paru dengan pengobatan OAT kategori I

\begin{tabular}{lllcc}
\hline & $\mathrm{n}$ & Median (min-maks) & Probabilitas \\
\hline $\begin{array}{l}\text { Konversi BTA pasien TB Paru pada kelompok } \\
\text { pemberian vitamin A }\end{array}$ & 15 & $2(2-4)$ & $<0,001$ \\
$\begin{array}{l}\text { Konversi BTA pasien TB Paru pada kelompok tanpa } \\
\text { pemberian vitamin A }\end{array}$ & 15 & $4(2-6)$ & \\
\hline
\end{tabular}

pasien yang tidak sembuh pada akhir pengobatan ${ }^{(15)}$

Pengaruh suplementasi vitamin A pada pengobatan pasien TB paru terhadap percepatan konversi dahak fase intensif. Hasil uji statistik Mann-Whitney diperoleh nilai $\mathrm{p}$ sebesar $<0,001$ yang masih dibawah nilai tingkat kemaknaan alpha sebesar 0,05 , artinya ada pengaruh suplementasi vitamin A pada pengobatan pasien TB paru terhadap percepatan konversi dahak pada fase intensif di Wilayah Kerja terhadap fungsi kekebalan tubuh manusia. Retinol tampaknya berpengaruh terhadap pertumbuhan dan diferensiasi limfosit B (leukosit yang berperan dalam proses kekebalan humoral). Disamping itu kekurangan vitamin A menurunkan respon antibodi yang bergantung pada sel-T (limfosit yang berperan pada kekebalan selular). Sebaliknya infeksi dapat memperburuk kekurangan vitamin $\mathrm{A}^{(19)}$. 


\section{SIMPULAN}

Waktu rata-rata konversi sputum pasien TB paru usia $\geq 18$ tahun, pengobatan OAT kategori 1 dengan IMT $\geq 18,5$ pada kelompok pemberian vitamin A $6000 \mathrm{IU}$ + OAT kategori I adalah 2,4 minggu, sedangkan pada kelompok yang hanya diberikan OAT kategori I, waktu rata-rata konversi sputum adalah 4,1 minggu. Ada pengaruh suplementasi vitamin A pada pengobatan pasien TB paru usia $\geq 18$ tahun, pengobatan OAT kategori 1 dengan IMT $\geq 18,5$ terhadap percepatan konversi dahak pada fase intensif di Wilayah Kerja Puskesmas Kecamatan Medan Kota. Pasien TB paru usia $\geq 18$ tahun, pengobatan OAT kategori 1 dengan IMT $\geq 18,5$ mayoritas berumur 18-27 tahun, berjenis kelamin laki-laki, pekerjaan adalah mahasiswa, pemeriksaan BTA pasien adalah $3+$, pada kelompok perlakuan konversi BTA pada minggu ke-2 dan pada kelompok kontrol konversi BTA pada minggu ke-4.

\section{DAFTAR PUSTAKA}

1. Kemenkes RI. Pusat data dan Informasi. Tuberkulosis, temukan, obati sampai sembuh. Jakarta. 2015. Hal: 1.

2. WHO. Global Tuberculosis Report 2015. $20^{\text {th }}$ edition. Geneva, Switzerland. 2015. p. 2, 5.

3. Kemenkes RI. Profil Kesehatan Indonesia Tahun 2015. Jakarta. 2016. Hal: 161, 365, 368.

4. Dinas Kesehatan Kota Medan. Laporan Kasus TB Paru 2013-2015.

5. Sekarindah T. Pengaruh pemberian vitamin A terhadap profil imun pasien tuberkulosis paru dengan terapi obat anti tuberkulosis [abstrak]. Perpustakaan Universitas Indonesia. Jakarta. 1992.

6. Marthur ML. Role of vitamin a suplplementation in the treatment of tuberculosis [abstract]. India. 2007. Jan-Feb;20(1):16-21.

7. Pakasi TA, Elvina K, Suratih NMD, Salean M, Darmawidjaja N, Bor $\mathrm{H}$, et al. Zinc and vitamin a supplementation fails to reduce sputum conversion time in severely malnourished pulmonary tuberculosis patients in Indonesia. Nutrition Journal 2010. 9:41.

8. Kemenkes RI. Pedoman nasional penanggulangan tuberkulosis. Jakarta. 2014. Hal: 128.

9. Dahlan MS. Statistik untuk kedokteran dan kesehatan. Penerbit Salemba Merdeka. Edisi Kelima. Jakarta. 2011.

10. Kemenkes RI. Standart prosedur operasional pemeriksaan mikroskopis TB. Direktorat Jenderal Bina Upaya Kesehatan, Direktorat Jenderal Pengendalian Penyakit dan Penyehatan Lingkungan.. Jakarta. 2012. Hal: 7.

11. WHO. Guideline: nutritional care and support for patients with tuberculosis. Geneva. 2013. p. 8-10.

12. Kemenkes RI. Riset Kesehatan dasar (Riskesdas). Badan Penelitian dan Pengembangan Kesehatan.
Jakarta. 2013. Hal: 70.

13. Tsani RM, Kasno. Gambaran klinis tuberkulosis paru di RSUP Dr. Kariadi Semarang Periode Januari-Juni 2011. Semarang. 2011. Hal: 37.

14. Ahmad I, Kushwaha R, Kant S, Natu SM, Singh SK, Usman K, et al. Role of vitamin a and zink supplementation on sputum conversion time in pulmonary tuberculosis patients. Erstwhile King George's Medical University. Journal Of Recent Advances In Applied Sciences (JRAAS) 28:63-68.

15. Nagpal M, Devgun P, Chawla N. A study on nutritional status and change in body mass index with treatment outcome in smear-positive pulmonary tb patients on dots in Amritsar City. India. 2014. International Journal of Medical Science and Public Health Vol 4 Issue 4. 454-457.

16. Pakasi TA, Karyadi E, Dolmans WM, Vandermeer $\mathrm{JW}$, Vandervelden $\mathrm{K}$, et al. Malnutrition and sociodemographic factors associated with pulmonary tuberculosis in Timor and Rote islands, Indonesia. Int J Tuberc Lung Dis 2009;13(6):755-9.

17. Karyadi E, West Ce, Schultink W, Nelwan Rh, Gross $\mathrm{R}$, Amin Z, et al. A double-blind, placebo-controlled study of vitamin a and zinc supplementation in persons with tuberculosis In Indonesia: Effects On Clinical Response And Nutritional Status, American Society for Clinical Nutrition. USA. Am J Clin Nutr.75:720-7.

18. Lettow V, Harries M, Kumwenda AD, Zijlstra JJ, Clark $\mathrm{EE}$, Taha TD. micronutrient malnutrition and wasting in adults with pulmonary tuberculosis with and without HIV coinfection in Malawi. 2004. BMC Infect Dis, 4 (1). p. 61. ISSN 1471- 2334 DOI:10.1186/14712334-4-61.

19. Almatsier S. Prinsip dasar ilmu gizi. Gramedia. Jakarta. 2013. Hal: 160. 